\title{
EXAMINATION OF MACRO AND MICRO ELEMENTS IN PSETTA MAKSIMA AND SOLEA VULGARIS FROM THE BLACK AND NORTH EASTERN MEDITERRANEAN SEAS
}

\author{
MUSTAFA KEMAL SANGUN ${ }^{a *}$, CEMAL TURAN $^{b}$, \\ BEYZA ERSOY ALTUN ${ }^{b}$
}

\begin{abstract}
The objective of this study was to determine the levels of essential ( $\mathrm{Ca}, \mathrm{K}, \mathrm{Na}, \mathrm{Mg}, \mathrm{Co}, \mathrm{Cu}, \mathrm{Cr}, \mathrm{Fe}, \mathrm{Mn}$ ) and non-essential (Al, As, $\mathrm{Ba}, \mathrm{Cd}, \mathrm{Ni}, \mathrm{Pb}, \mathrm{Sr}, \mathrm{Li}, \mathrm{B})$ elements in the muscle, liver and skin of $P$. maxima and S. vulgaris. Analysis of variance was performed to determine significant differences among tissues. There were no significant differences in the metal concentrations among the tissues of both species with the exception of $\mathrm{Fe}$ and $\mathrm{Li}$. The levels of essential metals such as $\mathrm{Na}, \mathrm{K}, \mathrm{Ca}$ and $\mathrm{Mg}$ were higher than $10 \mathrm{mg} / \mathrm{kg}$; Fe and Cu were lower than $10 \mathrm{mg} / \mathrm{kg}$. The results showed that the $P$. maksima and $\mathrm{S}$. vulgaris are a good dietary source of essential nutrients. However, the concentrations of some nonessential metals in tissues of $P$. maksima and $S$. vulgaris exceeded the acceptable values for human consumption.
\end{abstract}

Keywords: Psetta maksima, Solea vulgaris, elements, minerals, heavy metals.

\section{INTRODUCTION}

Due to the increased interest in defining the biological roles of nutrients and their function in the ethology of chronic diseases, knowledge of dietary nutrient intake is needed to optimize human health [1].

\footnotetext{
a Hatay Mustafa Kemal University, Faculty of Arts and Sciences, Department of Chemistry, 31060 Antakya, Hatay, Turkey

b Iskenderun Technical University, Faculty of Marine Science and Technology, 31200 Iskenderun, Hatay, Turkey

${ }^{*}$ Corresponding author ksangun@gmail.com
} 
Fish flesh is an important source of minerals. The contents of $\mathrm{K}, \mathrm{Na}$, $\mathrm{Mg}$ and $\mathrm{Ca}$ are up to $10 \mathrm{mg} / \mathrm{kg}$, whereas those of $\mathrm{Fe}$ and $\mathrm{Cu}$ are less than $10 \mathrm{mg} / \mathrm{kg}$ [2-4]. Many elements, which are present in seafood, are essential for human life at low concentrations and, however, they can be toxic at high concentrations. Therefore, many consumers regard any presence of these elements in fish as a hazard to health [5].

For the normal metabolism of fish, the essential metals must be taken up from waters, food or sediment. However, similar to the route of essential metals, non-essential ones are also taken by fish and accumulate in their tissues. Ecological need, sex, size and molt of marine animals were also found to affect metal accumulation in their tissues [6].

Many studies have been conducted on the elements in tissues of fish species in different parts of the world [7-14]. A few studies were done for metals in tissues of the $S$. vulgaris in literature, but it was not reported in Turkey. Moreover, there is no data for the $P$. maxima in literature.

The objective of this study was to determine the levels of both the various essential ( $\mathrm{Ca}, \mathrm{K}, \mathrm{Na}, \mathrm{Mg}, \mathrm{Co}, \mathrm{Cu}, \mathrm{Cr}, \mathrm{Fe}, \mathrm{Mn}$ ) and non-essential (Al, As, Ba, Cd, Ni, Pb, Sr, Li, B) elements in the muscle, liver and skin of two commercially valuable fish species $P$. maxima from the Black Sea and S. vulgaris from Iskenderun Bay, North Eastern Mediterranean Sea.

\section{RESULTS AND DISCUSSION}

The concentrations of the macro-microelements analysed in the muscle, liver and skin of $P$. maksima and $S$. vulgaris with means \pm standard deviation are given in Table 1 and Table 2.

Analysis of variance was performed to determined significant differences among tissues. Results from this analysis showed that there were no significant differences between the metal concentrations in the tissues of both species with the exception of Fe and Li.

The content $(\mathrm{mg} / \mathrm{kg})$ of muscle was $2931.27 \pm 234.48 \mathrm{mg} \mathrm{Na}$, $443.03 \pm 112.25 \mathrm{mg} \mathrm{K}, 414.73 \pm 132.82 \mathrm{mg} \mathrm{Ca}, 1744.38 \pm 309.36 \mathrm{mg} \mathrm{Mg}$. The levels of macro elements $\mathrm{Na}, \mathrm{K}, \mathrm{Ca}$ and $\mathrm{Mg}$ in a given muscle were always higher in $P$. maksima than in S. vulgaris. In P. maksima, the concentrations of $\mathrm{Na}, \mathrm{K}, \mathrm{Ca}, \mathrm{Mg}$ were highest in muscle. However, the highest concentrations in tissues of $S$. vulgaris were found in the liver and skin.

The $\mathrm{Ca}$ and $\mathrm{K}$ values in muscle of fish samples are lower and the $\mathrm{Na}, \mathrm{Mg}$ values are higher than that reported in M. potassou, M. merluccius, S. vulgaris from Mediterranean (Spain) and similar results reported from Baltic Herring [15-16]. 
Table 1. Levels (mg metal/kg, wt) of metals in the muscle, liver and skin of $P$. maksima.

\begin{tabular}{|c|r|r|r|}
\hline Element & Muscle & \multicolumn{1}{c|}{ Liver } & \multicolumn{1}{c|}{ Skin } \\
\hline $\mathrm{Na}$ & $2931.27 \pm 234.48^{*}$ & $2716.87 \pm 589.09$ & $2787.44 \pm 249.51$ \\
\hline $\mathrm{K}$ & $443.03 \pm 112.25$ & $132.93 \pm 42.79$ & $318.20 \pm 160.12$ \\
\hline $\mathrm{Ca}$ & $414.73 \pm 132.82$ & $283.25 \pm 50.01$ & $289.73 \pm 50.01$ \\
\hline $\mathrm{Mg}$ & $1744.38 \pm 309.36$ & $1191.78 \pm 104.03$ & $1729.56 \pm 361.22$ \\
\hline $\mathrm{Fe}$ & $3.26 \pm 1.58^{\mathrm{a}}$ & $64.67 \pm 31.53^{\mathrm{b}}$ & $4.48 \pm 1.82^{\mathrm{a}}$ \\
\hline $\mathrm{Cu}$ & $15.49 \pm 8.12$ & $3.85 \pm 1.51$ & $12.79 \pm 6.38$ \\
\hline $\mathrm{Mn}$ & $0.83 \pm 0.15$ & $10.50 \pm 4.89$ & $6.82 \pm 0.50$ \\
\hline $\mathrm{Ba}$ & $3.05 \pm 1.09$ & $5.92 \pm 0.43$ & $3.96 \pm 1.25$ \\
\hline $\mathrm{Li}$ & $4.35 \pm 1.71^{\mathrm{a}}$ & $8.59 \pm 2.32^{\mathrm{b}}$ & $8.59 \pm 0.55^{\mathrm{b}}$ \\
\hline $\mathrm{Ni}$ & $7.08 \pm 1.35$ & $27.83 \pm 4.58$ & $8.28 \pm 5.66$ \\
\hline $\mathrm{As}$ & $2.42 \pm 0.36^{\mathrm{b}}$ & $4.78 \pm 1.29$ & $2.16 \pm 0.13$ \\
\hline $\mathrm{Al}$ & $3.68 \pm 0.29^{\mathrm{a}}$ & $2.58 \pm 0.68$ & $3.56 \pm 2.06$ \\
\hline $\mathrm{B}$ & $\mathrm{ND}$ & $\mathrm{ND}$ & $\mathrm{ND}$ \\
\hline $\mathrm{Cd}$ & $0.13 \pm 0.09^{\mathrm{b}}$ & $0.15 \pm 0.10$ & $0.14 \pm 0.09$ \\
\hline $\mathrm{Co}$ & $0.71 \pm 0.06^{\mathrm{a}}$ & $0.35 \pm 0.11$ & $0.37 \pm 0.05$ \\
\hline $\mathrm{Cr}$ & $0.61 \pm 0.05^{\mathrm{a}}$ & $0.32 \pm 0.16$ & $0.78 \pm 0.31$ \\
\hline $\mathrm{Pb}$ & $1.11 \pm 0.05^{\mathrm{a}}$ & $0.54 \pm 0.33$ & $2.24 \pm 1.70$ \\
\hline $\mathrm{Sr}$ & $0.31 \pm 0.14$ & $0.53 \pm 0.14$ & $1.28 \pm 0.86$ \\
\hline
\end{tabular}

ND: Not determined [below the limits of detection].

$*$ Standard deviation is given with, $\pm n=3$ within the column values with different letters are significantly different $(P<0.05)$, values without letters are not significantly different $(P>0.05)$.

The $\mathrm{Na}, \mathrm{K}, \mathrm{Ca}$, and $\mathrm{Mg}$ concentrations in liver of $P$. maksima and $\mathrm{S}$. vulgaris were $2716.87-3147.34 \mathrm{mg} / \mathrm{kg}, 132.93-394.98 \mathrm{mg} / \mathrm{kg}, 283.25-382.82$ $\mathrm{mg} / \mathrm{kg}, 1191.78-2030.87 \mathrm{mg} / \mathrm{kg}$, respectively. The $\mathrm{Na}, \mathrm{Ca}, \mathrm{Mg}$ values in muscle and liver of fish samples are higher than those obtained by Ersoy in ten fish species from different region of North Eastern Mediterranean Sea (Turkey) [17]. The $\mathrm{K}$ value was found lower than reported [17].

The $\mathrm{Na}, \mathrm{K}, \mathrm{Ca}$, and $\mathrm{Mg}$ levels in skin of $P$. maksima and S. vulgaris ranged between 2787.44-3074.19 $\mathrm{mg} / \mathrm{kg}, 318.20-714.49 \mathrm{mg} / \mathrm{kg}, 289.73-$ $284.20 \mathrm{mg} / \mathrm{kg}, 1729.56-1160.62 \mathrm{mg} / \mathrm{kg}$, respectively. Although skin is a consumed part of the fish, it has not been investigated in previous studies.

Fe concentrations in muscle, liver and skin ranged between 3.26$64.67 \mathrm{mg} / \mathrm{kg}$ for P. maksima and ranged $3.42-112.90 \mathrm{mg} / \mathrm{kg}$ for S. vulgaris. The Fe concentrations in liver of two fish species-as opposed to the skin 
and muscle increased significantly $(\mathrm{P}<0.05)$. The organs, such as the liver, gonads, kidney and gills are metabolically active tissues and accumulate metals of higher levels [18-19].

Table 2. Levels (mg metal/ $\mathrm{kg}$, wt) of metals in the muscle, liver and skin of $S$. vulgaris.

\begin{tabular}{|c|r|r|r|}
\hline Element & \multicolumn{1}{|c|}{ Muscle } & \multicolumn{1}{c|}{ Liver } & \multicolumn{1}{c|}{ Skin } \\
\hline $\mathrm{Na}$ & $2064.85 \pm 365.02^{*}$ & $3147.34 \pm 332.06$ & $3074.19 \pm 1087.69$ \\
\hline $\mathrm{K}$ & $330.78 \pm 62.60$ & $394.98 \pm 342.45$ & $714.49 \pm 10.03$ \\
\hline $\mathrm{Ca}$ & $232.41 \pm 16.39$ & $382.82 \pm 193.62$ & $284.20 \pm 117.08$ \\
\hline $\mathrm{Mg}$ & $1726.19 \pm 155.42$ & $2030.87 \pm 1500.60$ & $1160.62 \pm 107.23$ \\
\hline $\mathrm{Fe}$ & $3.42 \pm 0.45^{\mathrm{a}}$ & $112.90 \pm 45.60^{\mathrm{b}}$ & $32.06 \pm 08.95^{\mathrm{a}}$ \\
\hline $\mathrm{Cu}$ & $11.90 \pm 4.62$ & $58.17 \pm 48.20$ & $4.54 \pm 1.63$ \\
\hline $\mathrm{Mn}$ & $8.04 \pm 3.92$ & $9.01 \pm 6.41$ & $1.72 \pm 0.40$ \\
\hline $\mathrm{Ba}$ & $4.35 \pm 1.44$ & $2.09 \pm 1.38$ & $8.29 \pm 6.40$ \\
\hline $\mathrm{Li}$ & $9.41 \pm 3.52$ & $24.50 \pm 21.91$ & $4.18 \pm 1.45$ \\
\hline $\mathrm{Ni}$ & $16.13 \pm 9.71$ & $12.13 \pm 7.61$ & $6.84 \pm 0.86$ \\
\hline $\mathrm{As}$ & $12.07 \pm 0.19^{\mathrm{b}}$ & $2.98 \pm 1.18$ & $1.57 \pm 0.48$ \\
\hline $\mathrm{Al}$ & $3.06 \pm 1.17$ & $2.47 \pm 0.72$ & $4.49 \pm 2.63$ \\
\hline $\mathrm{B}$ & $\mathrm{ND}$ & $\mathrm{ND}$ & $\mathrm{ND}$ \\
\hline $\mathrm{Cd}$ & $0.39 \pm 0.04^{\mathrm{b}}$ & $0.20 \pm 0.14$ & $0.17 \pm 0.01^{\mathrm{a}}$ \\
\hline $\mathrm{Co}$ & $0.34 \pm 0.05^{\mathrm{b}}$ & $0.20 \pm 0.19$ & $0.44 \pm 0.05$ \\
\hline $\mathrm{Cr}$ & $0.02 \pm 0.01^{\mathrm{b}}$ & $0.37 \pm 0.06^{\mathrm{a}}$ & $13.33 \pm 0.21^{\mathrm{a}}$ \\
\hline $\mathrm{Pb}$ & $0.71 \pm 0.60$ & $1.41 \pm 1.20$ & $1.65 \pm 0.16$ \\
\hline $\mathrm{Sr}$ & $1.00 \pm 0.14$ & $1.39 \pm 0.56$ & $4.24 \pm 2.90$ \\
\hline
\end{tabular}

ND: Not determined [below the limits of detection].

*Standard deviation is given in parenthesize, $n=3$ within the column values with different letters are significantly different $(P<0.05)$, values without letters are not significantly different $(P>0.05)$.

The Fe level in muscle of fish samples was similar to those reported by numerous studies in fish species from different areas [13, 20-22]. The Fe values in liver are similar to reported by Ersoy and Yilmaz in different fish species $[13,17]$.

The Fe levels $(4.48-32.06 \mathrm{mg} / \mathrm{kg})$ in skin of both species are lower than that reported by Yilmaz in $M$. cephalus and $T$. mediterraneus from Iskenderun Bay [23]. 
The Mn values in tissues of fish samples ranged from 0.83 to 10.50 $\mathrm{mg} / \mathrm{kg}$ for $P$. maksima and ranged from 1.72 to $9.01 \mathrm{mg} / \mathrm{kg}$ for $S$. vulgaris. The Mn levels in muscle of $P$. maksima and $S$. vulgaris was similar to those reported by numerous studies in fish species from different areas $[9,17,20,21]$. The Mn values in liver were higher than that reported by Ersoy [17]. There is no data concerning Mn level in skin of fish.

The $\mathrm{Cu}$ concentrations in muscle, liver and skin ranged from 3.85 to $15.49 \mathrm{mg} / \mathrm{kg}$ for P. maksima and ranged from 4.54 to $58.17 \mathrm{mg} / \mathrm{kg}$ for $S$. vulgaris. The Cu results in muscle of $S$. vulgaris reported by other researcher were much lower than our values $[8,9,15]$. However, the values in liver of this species are similar to our values determined in liver. On the other hand, the values in muscle of $P$. maksima and $S$. vulgaris are similar to those reported [24]. The $\mathrm{Cu}$ level in skin of fish samples is similar to those obtained by Yilmaz $[13,23]$.

According to the regulations which made by commission of European Union and Turkey, permissible limit for $\mathrm{Cu}$ in muscle of fish is 20 $\mathrm{mg} / \mathrm{kg}$ wet weight [25]. The Cu levels in muscle of both species were not exceed given consumption levels. The $\mathrm{Pb}$ values in muscle, liver and skin of fish samples were $0.71-1.11 \mathrm{mg} / \mathrm{kg}, 0.54-1.41 \mathrm{mg} / \mathrm{kg}, 1.65-2.24 \mathrm{mg} / \mathrm{kg}$, respectively. The $\mathrm{Pb}$ concentrations in muscle of two fish species are similar to those reported by Yilmaz [23]. However, some researcher reported that the $\mathrm{Pb}$ concentrations in muscle and liver of different fish species from other areas were much lower than in $\mathrm{Pb}$ values determined in our study $[20,26]$. The $\mathrm{Pb}$ values in skin of fish samples were lower than obtained by Yilmaz [23].

The $\mathrm{Cd}$ concentrations in muscle, liver and skin ranged between $0.13,0.15$ and $0.14 \mathrm{mg} / \mathrm{kg}$ for $P$. maksima and between $0.39,0.20$ and 0.17 $\mathrm{mg} / \mathrm{kg}$ for $\mathrm{S}$. vulgaris, respectively. The results of $\mathrm{Cd}$ levels in muscle and liver of $S$. vulgaris are similar to those reported for the $S$. vulgaris from other areas [8-9]. The Cd results in muscle of $P$. maksima and $S$. vulgaris in agreement with those reported in numerous studies $[6,21,28]$. There is no data concerning the $\mathrm{Cd}$ values in skin of fish. The $\mathrm{Cd}$ value in muscle of $P$. maksima and $S$. vulgaris exceed acceptable value for $\mathrm{Cd}$ in muscle of fish is $0.1 \mathrm{mg} / \mathrm{kg}$ wet weight for human consumption designated by the regulations [25]. From the fish health point of view, the $\mathrm{Cd}$ value in muscle of fish samples may also be considered as an important warning signal.

As concentrations in muscle, liver and skin for $P$. maksima were 2.42, 4.78 and $2.16 \mathrm{mg} / \mathrm{kg}$, respectively. These values for $S$. vulgaris were 12.07 , 2.98 and $1.57 \mathrm{mg} / \mathrm{kg}$, respectively. The As values in muscle and liver of $S$. vulgaris were much higher in the same species $[9,21]$. Mormede \& Davies found lower levels of As in different fish from the Rockall Trough [26]. The As 
levels in muscle of fish is $1 \mathrm{mg} / \mathrm{kg}$ wet weight due to the regulations in Turkey [25]. The As value in muscle of fish samples exceed acceptable values. Especially, The As values in muscle of $S$. vulgaris were significantly high.

The $\mathrm{Cr}$ and $\mathrm{Ni}$ concentrations in muscle for fish species obtained were $0.02-0.61 \mathrm{mg} / \mathrm{kg}$ and $7.08-16.13 \mathrm{mg} / \mathrm{kg}$, respectively. The $\mathrm{Cr}$ values muscle of fish samples are similar to those obtained by numerous studies in fish from different areas $[7,9,20]$. However, some researchers found much higher levels of $\mathrm{Cr}$ in muscle of North Eastern Mediterranean fish [6,29].

The $\mathrm{Cr}$ and $\mathrm{Ni}$ concentrations in liver of fish samples were found $0.32-0.37,12.13-27.83 \mathrm{mg} / \mathrm{kg}$, respectively. The $\mathrm{Cr}$ contents in liver of $P$. maksima and $S$. vulgaris was lower than reported in Mediterranean Fish $[6,29]$. However, lower values of $\mathrm{Cr}$ found in S. vulgaris from other areas [9]. Ni concentrations in muscle and liver for S. vulgaris and P. maksima were higher than reported $[6,29]$. The $\mathrm{Cr}$ and Ni values in skin of $P$ maksima were $0.78 \mathrm{mg} / \mathrm{kg}$ and $8.28 \mathrm{mg} / \mathrm{kg}$. However, the values of $S$. vulgaris in skin were $13.33 \mathrm{mg} / \mathrm{kg} \mathrm{Cr}$ and $6.84 \mathrm{mg} / \mathrm{kg} \mathrm{Ni}$. The $\mathrm{Cr}$ values in skin of fish samples are similar for $M$. cephalus and $T$. mediterraneus [23]. Whereas the $\mathrm{Ni}$ content is skin was higher than reported by the same researcher [23].

The Co concentrations in muscle, liver and skin of $P$. maksima were $0.71,0.35$ and $0.37 \mathrm{mg} / \mathrm{kg}$, respectively. This values for $S$. vulgaris were $0.34,0.20,0.44 \mathrm{mg} / \mathrm{kg}$, respectively. The results of Co in muscle of $P$. maksima and $S$. vulgaris are similar to those reported for fish from Black Sea Coast in Turkey [20]. These results in muscle were lower than reported [28]. The concentrations in liver and skin of fish have not been studied in previous works.

The Al concentration in muscle of $S$. vulgaris and $P$. maksima was 3.06 and $3.68 \mathrm{mg} / \mathrm{kg}$, respectively. The Al concentrations in liver and skin of fish ranged from 2.7 to $4.48 \mathrm{mg} / \mathrm{kg}$. There is no data concerning the Al values in tissues.

The $\mathrm{Ba}, \mathrm{Li}, \mathrm{Sr}$ and $\mathrm{B}$ were also obtained in different tissues of $P$. maksima and S. vulgaris. The Ba concentrations in tissues of both species ranged from 2.09 to $8.29 \mathrm{mg} / \mathrm{kg}$. The Li concentration in tissues of fish samples ranged between $4.18-24.50 \mathrm{mg} / \mathrm{kg}$. The Li values in muscle of P.maksima reduced significantly $(\mathrm{P}<0.05)$ according to liver and skin of the same species. The Sr concentrations in muscle, liver and skin of two fish species were between 0.31-1, 0.53-1.39, 1.28-4.24 mg/kg, respectively. The B concentrations in muscle, liver and skin of fish samples were not detectable (below limits of detection). Unfortunately, there are no data concerning the $\mathrm{Ba}, \mathrm{Li}, \mathrm{Sr}$ and $\mathrm{B}$ concentrations in muscle, liver and skin of the marine fish. 


\section{CONCLUSIONS}

The elements in tissues of $P$. maksima have not been investigated in previous studies. Data concerning mineral content of $S$. vulgaris was not reported in Turkey. Hence, the present study might be accepted as representative data for $P$. maksima and $S$. vulgaris that the species are studied firstly at this region.

The obtained results provided evidence that the studied $P$. maksima and S. vulgaris are a good dietary source of essential macro-micronutrients and the levels of some metals were even higher than acceptable values for human consumption.

These results can also be used to test the chemical quality of the marine food, in order to evaluate the possible risk associated with their consumption by human.

Further studies are needed to determine these minerals might have on the health of the consumer.

\section{EXPERIMENTAL SECTION}

\section{Materials and Methods}

\section{Samples Preparation}

The $P$. maksima samples were obtained from Şile in the Black Sea Coast and S. vulgaris samples were obtained from Iskenderun Bay in North eastern Mediterranean Sea.

Periodically taken fishes samples were kept in cold iced boxes and transported into Mustafa Kemal University, Science, Research and Application Center (MKUFAM), Tayfur Sökmen Campus, Antakya, as soon as probable under standard conditions. MKUFAM Lab was completed digestion and elements analyses.

\section{Digestion Procedures}

For analyses, approximately $0.5 \mathrm{~g}$ sample was digested with $10 \mathrm{~mL}$ high purity nitric acid (Merck) in CEM® Mars5 (Version 045012) microwave. The conditions of the digestion are $10 \mathrm{~min}$. for ramp time, 10 min hold time at $210^{\circ} \mathrm{C}$ and $200 \mathrm{Psi}$. After digestion the samples filtered through Whatman ${ }^{\circledR}$ quantitative (No: $42,110 \mathrm{~mm}{ }^{\star}$ ) filter papers. Laboratory grade hydrochloric acid is added into the initial digested and the sample is refluxed. This digested samples are filtered and the filter paper and residues are rinsed with hot hydrochloric acid and then hot reagent water. Filter paper and residue are returned to the digestion flask, refluxed with extra hydrochloric 
and then filtered again. The digested portion is then diluted to a final volume of $20 \mathrm{ml}$ [30]. A blank digest was carried out in the same way. All metals were determined against aqueous standards.

At least three replicates for each sample was prepared in order to increase sensitivity in readings.

\section{Analytic Procedures}

Determination of all metal concentrations was carried out by inductively coupled plasma atomic emission spectrometry (ICP-AES) (Varian modelLiberty Series II). For the calibration of the ICP-AES a High Purity® Multi Standards was used. The following emission lines were used; As 189.041, $\mathrm{Ca}$ 393.366, Cd 228.802, Co 228.616, Cr 367.716, Cu 324.754, Fe 259.940, K 766.490, Mg 279.553, Mn 257.610, Na 588.995, Ni 221.647, Pb 220.353, Al 396.152, Ba 455.403, Sr 407.771, Li 670.784, B 249.773. Metal concentrations were calculated $\mathrm{mg} / \mathrm{kg}$ wet weight.

\section{Statistical Analysis}

Analysis of variance was used to evaluate the analysis data, and significant differences among means were determined by One-way analysis of variance (ANOVA) and Duncan's Multiple Range Test $(P=0.05)$ (SPSS 12 for windows).

\section{REFERENCES}

1. W. Sawaya, F. Al-Awadi, N. Eid, B. Dashti, Food composition, Kuwaiti composite dishes (1st ed.). Kuwait: Kuwait Institute for Scientific Research 1998.

2. U. Kietzman, K. Priebe, D. Rakow, K. Reichstein, Ictiologia general. In inspeccion veterinaria de pescados (editorial acribia) Zaragoza, Spain, 1974, p. 21.

3. A.A. Paul, D.A.T. Southgate, The composition of foods. Amsterdam: Elsevier Science Ltd. 1978.

4. M.P. Navarro, Review Agroquim Tecnology Alimentarius, 1991, 31, 330.

5. J. Oehlenschlager, Identifying heavy metals in fish. In H.A. Bremmer, Safety and quality issues in fish processing Woodhead Publishing Limited and CRC Press LLC. 2002, p. 95.

6. M. Canli, G. Atli, Environmental Pollution, 2003, 121, 129.

7. K. Chandrashekar, Y.G. Deosthale, Journal of Food Composition and Analysis, 1993, 6(2), 195.

8. A. Hamza-Chaffai, M. Roméo, A. El Abed, Bulletin Environmental Contamination and Toxicology, 1996, 56, 766. 
9. J. Usero, C. Izquierdo, J. Morillo, I. Gracia, Environment International, 2003, 29, 949.

10. X. Wang, T. Sato, B. Xing, S. Tao, Science of the Total Environment, 2005, $350,28$.

11. P. Herman, S. Harangi, M. Fehér, I. Fábián, E. Baranyai, Studia Univ. BabesBolyai Chem., 2017, 62(2), 213.

12. M. Turkmen, Y. Tepe, A. Türkmen, M.K. Sangun, A. Ateş, E. Genç, Bull. Environ. Contam. Toxicol. 2013, 90, 702.

13. A.B. Yılmaz, M.K. Sangun, D. Yağlıoglu, C. Turan, Food Chem. 2010,123, 410.

14. D. Ayas, A. Kosker, G. Agilkaya, M. Bakan, D Yaglioglu, Natural and Engineering Sciences, 2018, 3(3), 248.

15. I. Martínez-Valverde, M.J. Periago, M. Santaella, G. Ros, Food Chemistry, 2000, 71, 503.

16. R. Tahvonen,T. Aro, J. Nurmi, H. Kallio, Journal of Food Composition and Analysis, 2000, 13, 893.

17. B. Ersoy, Nutrient composition and heavy metal contents of the fish consumed during the hunting season in the northeast Mediterranean (Adana-Karataş) region. Cukurova University, PhD Thesis. Adana, 2006, p142.

18. P. Allen, Toxicology and Environmental Chemistry, 1994, 44, 101.

19. P. Allen, Archives of Environmental Contamination and Toxicology, 1995, 29, 8.

20. S. Topcuoglu, C. Kirbasoglu, N. Gungor, Environment International, 2002, 27, 521.

21. M. Tuzen, Food Chemistry, 2003, 80, 119.

22. M. Eken, F. Turan, F. Aydın, S. Karan, Natural and Engineering Sciences, 2018, 3(2), 169.

23. A.B. Yilmaz, Environmental Research, 2003, 92, 277.

24. F. Kargin, Water Air Soil and Pollution, 1996, 90, 557.

25. European Community, Rule N.466, European Official Gazette, 16th Marc 2001.

26. S. Mormede, I. M. Davies, Continental Shelf Research, 2001, 21, 899.

27. Council of Europe, Resolution AP (96) 4 on maximum and guideline levels and on source directed measures aimed at reducing the contamination of food by lead, cadmium and mercury. Adopted by the Committee of Ministers on 2 October 1996.

28. C. Tamira, S.Q.H. Shane, R.F. Ambrose, Marine Pollution Bulletin, 2001, 42(3), 224.

29. M. Kalay, O. Ay, M. Canli, 1999 Bulletin Environmental Contamination and Toxicology, 2001, 63, 673.

30. M.K. Sangun, H.G. Ozdilek, Asian Journal of Chemistry, 2007, 19(1), 621. 
